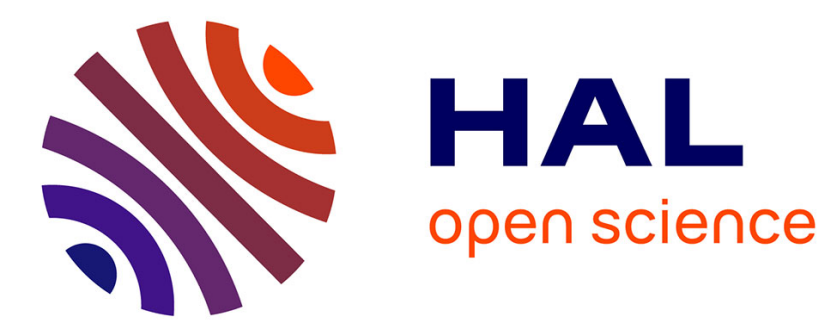

\title{
CHEMISTRY OF ANTARCTIC SNOW AND ICE
}

Michel Legrand

\section{To cite this version:}

Michel Legrand. CHEMISTRY OF ANTARCTIC SNOW AND ICE. Journal de Physique Colloques, 1987, 48 (C1), pp.C1-77-C1-86. 10.1051/jphyscol:1987111 . jpa-00226251

\section{HAL Id: jpa-00226251 https://hal.science/jpa-00226251}

Submitted on 1 Jan 1987

HAL is a multi-disciplinary open access archive for the deposit and dissemination of scientific research documents, whether they are published or not. The documents may come from teaching and research institutions in France or abroad, or from public or private research centers.
L'archive ouverte pluridisciplinaire HAL, est destinée au dépôt et à la diffusion de documents scientifiques de niveau recherche, publiés ou non, émanant des établissements d'enseignement et de recherche français ou étrangers, des laboratoires publics ou privés. 


\title{
CHEMISTRY OF ANTARCTIC SNOW AND ICE
}

\author{
M. LEGRAND
}

Laboratoire de Glaciologie et Géophysique de I'Environnement B.P. 96, F-38402 St-Martin-d'Hères Cedex, France

\section{RESUME}

Mille échantillons de neige et glace de l'Antarctique de l'Est et de l'Ouest (régions côtières et centrales) ont été étudiés. L'échantillonnage couvre differentes periodes de temps jusqu'a $30_{+}, 000$ ans $B . P$. Dans 1 'eau de fusion, nous avons mesure les ions majeurs ( $\mathrm{Na}^{+}, \mathrm{NH}_{4}^{+}, \mathrm{K}^{+}, \mathrm{Ca}^{++}, \mathrm{Mg}^{++}, \mathrm{H}^{+}, \mathrm{Cl}^{-}$, $\mathrm{NO}_{3}^{-}$et $\mathrm{SO}_{4}$ ) en s'affranchissant des contaminations. Le bon equilibre observe entre les cations et les anions permet d'établir le catalogue des composés chimiques présents dans la neige et la glace antarctiques.

En régions côtières, la neige contient surtout du sel de mer $\left(14 \mu^{E q} \cdot 1^{-1}\right)$ et deux acides $\mathrm{HNO}_{3}(0.8)$ et $\mathrm{H}_{2} \mathrm{SO}_{4}(1.2)$. Plus a l'intérieur du continent, le sel de mer devient beaucoup moins important ( $30 \%$ du total des ions), les acides devenant prédominants ( $\mathrm{HNO}_{3}, \mathrm{H}_{2} \mathrm{SO}_{4}$ et parfois $\mathrm{HCl}$, dans des proportions variables d'un site a 1 'autre). Ces especes solubles représentent la presque totalité des impuretés (90 a $95 \%$ en masse).

La chimie de la neige datant de la dernière periode glaciaire (il y a 18.000 ans) est plus compliquee. En effet, les impuretés insolubles (aluminosilicates) deviennent importantes ( $60 \%$ en masse, contre 5 a $10 \%$ durant 1 'Holocene). De plus les contributions marines ( $\mathrm{sel}$ de mer) et terrigènes ( $\mathrm{CaSO}_{4}, \mathrm{MgSO}_{4}$ ) augmentent tandis que la contribution des acides n'évolue guère. Sel de mer ( $55^{4}$ ) terrigene $(25 \%)$ et acides ( $20 \%$ ) est une composition typique des impuretés solubles de cette vieille glace.

La variation du flux de retombere en fonction du taux d'accumulation montre que les impuretes particulaires de 1 'atmosphere (sel de mer, $\mathrm{H}_{2} \mathrm{O}-\mathrm{H}_{2} \mathrm{SO}_{4}$ ) sont incorporées dans la neige par dépôt sec et humide. En région's centrales le dépót sec représente 60 a $70 \%$ du depôt total. Par contre cette fraction semble plus faible pour $\mathrm{HNO}_{3}$ (présent a l'état gazeux dans l'atmosphere antarctique). L'incorporation de $\mathrm{HNO}_{3}$ dans la neige demeure cependant mal comprise.

\section{ABSTRACT}

We have studied 1000 samples of snow and ice from East and West Antarctica (coastal as well as central areas). These samples cover different time periods up to $30, q 00$ years $B_{+} \cdot P_{+}$. In the meltwater, we have measured major ions (i.e. Na, $\mathrm{NH}_{4}{ }^{+}, \mathrm{K}^{+}, \mathrm{Ca}^{++}, \mathrm{Mg}^{++}, \mathrm{H}^{+}, \mathrm{Cl}$, $\mathrm{NO}_{3}$, and $\mathrm{SO}_{4}{ }^{+}$, using stringent contamination free tehniques. A very close balance between anions and cations is observed, making it possible to draw up the list of chemical compounds present in antarctic snow and ice.

In coastal areas, snow contains essentially sea salt $\left(14 \mu \mathrm{Eq} .1^{-1}\right)$ and two acids : $\mathrm{HNO}_{3}(0.8)$ and $\mathrm{H}_{2} \mathrm{SO}_{4}(1.2)$. In more central areas, the sea salt contribution 
decreases strongly ( $30 \%$ of the total ionic budget). Acids represent the preponderant part ( $\mathrm{HNO}_{3}, \mathrm{H}_{2} \mathrm{SO}_{4}$ and sometimes $\mathrm{HCl}$ being present in variable proportions depending on the location). These soluble species represent the greatest part of total impurities ( 90 to $95 \%$ by mass).

The chemistry of the ice deposited during the late glacial age $(18,000$ years B.P.) is more intricate. Indeed, insoluble species (i.e. aluminosilicates) content is enhanced ( $50 \%$ by mass, against 5 to $10 \%$ during the Holocene). Besides, marine (sea salt) and terrestrial ( $\mathrm{CaSO}_{4}, \mathrm{MgSO}_{4}$ ) contributions increase whereas acids contribution remains stable. Sea saft ( $55 \%)$, terrestrial species (25\%) and acids $(20 \%)$ is a typical composition of soluble impurities in this aged ice.

The dependence of deposition fluxes with the accumulation rate demonstrates that particulate impurities (i.e. sea salt and $\mathrm{H}_{2} \mathrm{O}-\mathrm{H}_{2} \mathrm{SO}_{4}$ ) in the atmosphere are incorporated in snow both by wet and dry deposition. Typically, dry deposition represents 60-70\% of the total deposition in central areas. On the other hand, this fraction seems to be weaker for $\mathrm{HNO}_{3}$ (present in gaseous phase in the Antarctic atmosphere). However, the incorporation of $\mathrm{HNO}_{3}$ in snow remains poorly understood.

\section{INTRODUCTION}

Substances present in polar snow include insoluble and soluble impurities in the lattice and gases trapped in bubbles enclosed in ice. Permanent gases ( $\mathrm{CO}_{2}$ for instance) do not interact with the ice, this question is still open concerning trace gases $\left(\mathrm{N}_{2} O\right.$, for example). These questions will not be discussed in this paper.

Insoluble species present in polar snow and ice are essentially in the form of aluminosilicates, and are emitted by continental sources (Petit et al. (1)). They are present at a few parts per billion ( $\mathrm{ppb}$ ) level in Antarctic snow layers deposited during the present climatic conditions ( $O$ to 10,000 years B.P.). Due to an enhanced poleward transport and a more dry environment at continents during the 18,000 years B.P. period, concentrations can reach several hundreds ppb in polar snow during this time period (Cragin et al. (2), Petit et al. (3), De Angelis et al. (4)).

In recent snow layers, soluble species (able to liberate ions in meltwater) are present in the range 1 to $500 \mathrm{ppb}$ in most cases and thereby represent the greatest part (in mass) of the total content. Over the last few years, many studies had been performed to determine ions, among them $\mathrm{Na}^{+}, \mathrm{Cl}^{-}, \mathrm{NO}_{3}{ }^{-}, \mathrm{SO}_{4}{ }^{-2}$ and $\mathrm{H}^{+}$, in meltwater, but these studies were never comprehensive.

More recently, a very_close balance between cations (i.e. $\mathrm{Na}^{+}, \mathrm{NH}_{4}^{+}, \mathrm{K}^{+}, \mathrm{Ca}^{++}, \mathrm{Mg}^{++}$, and $\mathrm{H}^{+}$) and anions ( $\mathrm{Cl}^{-}, \mathrm{NO}_{3}^{-}$and $\mathrm{SO}_{4}{ }^{-}$) was obtained in meltwater of shallow snow layers at the South Pole (Legrand and Delmas (5)), at several locations in Adelie Land (Legrand and Delmas (6)) and of core sections from the $2000 \mathrm{~m}$ deep Byrd ice core (Palais and Legrand (7)). These studies have demonstrated that the majority of the soluble impurities is in the form of acids (i.e. $\mathrm{HCl}$, $\mathrm{HNO}_{3}$ and $\mathrm{H}_{2} \mathrm{SO}_{4}$ in variable proportions depending on the location) except near the coast where the sea salt is predominant. Besides the chemistry of the ice deposited during the late glacial maximum $(18,000$ years B.P.) is generally more intricate (Legrand (8)).

This study is focused on major soluble species and its objective is threefold. First we examine the ionic balance. Then we present a list of chemical compounds present in snow deposited during recent years, but also during the late glacial maximum. Second, in order to have an overview, we report on the spatial variations of snow composition (Byrd in West Antarctica, South Pole in Central Antarctica, 
Dome $\mathrm{C}$ and few locations of Adelie Land in East Antarctica). A comparison with Greenland is also established. Third, we study the fallout variation of some compounds with accumulation rate and discuss briefly the incorporation of these impurities in snow, taking into account their physical states in the atmosphere.

\section{EXPERIMENTAL}

In order to establish the ionic balance of meltwater, we have determined all ions except $\mathrm{H}^{+}$(i.e. $\mathrm{Na}^{+}, \mathrm{NH}_{4}^{+}, \mathrm{K}^{+}, \mathrm{Ca}^{++}, \mathrm{Mg}^{++}, \mathrm{Cl}^{-}$, $\mathrm{NO}_{3}^{-}$and $\mathrm{SO}_{4}^{-}$) by ion chromatography (I.C.) with a typical analytical precision of $5 \frac{3}{10} \%$ in most cases (Legrand et a1.

(9)). Based on the ionic exchange between a liquid phase (meltwater sample and eluent) and the stationary phase (resin), this method is supposed to measure only the soluble part of an element (or compound) present in the meltwater. However we have noted that sodium is an exception to this rule. Indeed, as will be discussed later, in Antarctic ice and particularly during the glacial age, this element is produced both by sea salt and terrestrial dust. In a core section from Dome $C$ (at $530 \mathrm{~m}$ depth i.e. 17,500 years B.P.) we have measured $\mathrm{Na}, \mathrm{Ca}, \mathrm{Mg}$ and $\mathrm{K}$ by ion chromatography and two other methods which are assumed to measure the total content (neutronic activation N.A. and atomic absorption A.A.). These measurements are performed both in the meltwater and in the filtered sample (using a $\leq 0.4$ um porosity filter). As clearly pointed in Table 1 , the terrestrial contribution is here significant (as suggested by the aluminium content) and the crustal derived sodium is insoluble in meltwater, but is completely dissolved when passing through the ion chromatographic columns. This phenomenon is not observed with other elements for which the ion chromatography measures only the soluble part. We have therefore determined aluminium content by neutronic activation when the terrestrial contribution becomes significant and corrected our sodium values by subtracting the crustal contribution evaluated by the relationship :

$\mathrm{Na}_{\mathrm{T}}=0.25 \mathrm{Al}$ (in $\mathrm{ppb}$ ) where 0.25 is $\mathrm{Na} / \mathrm{Al}$ in the mean crustal composition

(Taylor $1964(10)$ )

\begin{tabular}{|c|c|c|c|c|c|}
\hline SAMPLE & $\begin{array}{l}\text { SODIUM } \\
\text { A.N. I.C. }\end{array}$ & $\begin{array}{l}\text { CALCIUM } \\
\text { A.A. I.C. }\end{array}$ & $\begin{array}{l}\text { MAGNESIUM } \\
\text { A.A. I.C. }\end{array}$ & $\begin{array}{l}\text { POTASSIUM } \\
\text { A.A. I.C. }\end{array}$ & $\begin{array}{c}\text { ALUMINIUM } \\
\text { A.N. }\end{array}$ \\
\hline $\begin{array}{l}\text { Before } \\
\text { filtration }\end{array}$ & 110 & 47 & 17.5 & 45 & 106 \\
\hline $\begin{array}{l}\text { After } \\
\text { filtration }\end{array}$ & 89. & 48.5 & 16.5 & 8.2 & 5.3 \\
\hline
\end{tabular}

Table 1 : Sodium, Calcium, Magnesium, Potassium and Aluminium content (in ppb) obtained in meltwater and the corresponding filtered sample $(\leq 0.4$ um) by several. analytical methods

Beside these major ions present at least at $1 \mathrm{ppb}$ level, other ions such as $\mathrm{F}^{-}, \mathrm{Br}^{-}$, $\mathrm{NO}_{2}, \mathrm{HCOO}^{-}$, and $\mathrm{CH}_{3} \mathrm{COO}^{-}$were found to be below the limit of detection in Antarctic snow (that is to say at maximum content of few tenths of ppb. (Legrand (9)).

Snow meltwater readily dissolves $\mathrm{CO}_{2}$ of the ambient atmosphere and frop bubbles in the ice. Then the weak carbonic acid formed modifies the initial $\mathrm{H}^{+}$content of snow. Therefore the usual measurement of $\mathrm{pH}$ in the meltwater does not offer a satisfactory description of the $\mathrm{H}^{+}$content in order to establish the ionic balance of snow. So we have used an acid titration method which eliminates the influence of $\mathrm{CO}_{2}$ occuring during the melting step (precision $\pm 0: 2 \mu \mathrm{Hq} .1^{-1}$, Legrand et al. (11) $)^{2}$ 


\section{IONIC BALANCE AND ORIGIN OF IONS}

With the aim of studying the ionic budget it is convenient to calculate on each sample the two following parameters $\Delta \mathrm{C}$ (which is used to examine how well the sum of cations balances the sum of anions) and $\Sigma$ (which represents the total ionic burden) :

$$
\begin{aligned}
\Delta \mathrm{C} & =[\mathrm{Na}]+\left[\mathrm{NH}_{4}^{+}\right]+\left[\mathrm{K}^{+}\right]+\left[\mathrm{Ca}^{++}\right]+\left[\mathrm{Mg}^{++}\right]+\left[\mathrm{H}^{+}\right]-[\mathrm{Cl}]-\left[\mathrm{NO}_{3}\right]-\left[\mathrm{SO}_{4}^{-}\right](2) \\
\Sigma & =\left[\mathrm{Na}^{+}\right]+\left[\mathrm{NH}_{4}^{+}\right]+\left[\mathrm{K}^{+}\right]+\left[\mathrm{Ca}^{++}\right]+\left[\mathrm{Mg}^{++}\right]+\left[\mathrm{H}^{+}\right]+[\mathrm{Cl}]+\left[\mathrm{NO}_{3}\right]+\left[\mathrm{SO}_{4}^{-}\right](3)
\end{aligned}
$$

(with concentrations expressed in $\mu \mathrm{Eq} \cdot 1^{-1}$ )

As above mentioned (see analytical section) our sodium values in these two equations have been corrected with regard to the terrestrial contribution, whenever it is necessary.

In the majority of our samples, the $\Delta \mathrm{C}$ is very low $\left(\leqslant 0.7 \mu \mathrm{Eq} .1^{-1}\right.$ i.e. less than $10 \%$ of $\Sigma$ ) (an example is given in figure 2). Therefore taking into account experimental errors, all samples are in ionic balance and we can write :

$$
[\mathrm{Na}]+\left[\mathrm{NH}_{4}^{+}\right]+\left[\mathrm{K}^{+}\right]+\left[\mathrm{Ca}^{++}\right]+\left[\mathrm{Mg}^{++}\right]+\left[\mathrm{H}^{+}\right]=\left[\mathrm{Cl}^{+}\right]+\left[\mathrm{NO}_{3}\right]+\left[\mathrm{SO}_{4}^{-}\right]
$$

Since $\left[\mathrm{NH}^{+}\right]$has been observed at very low levels $\left(\leq 0.2 \mathrm{uEq} .1^{-1}\right.$, i.e. less than $3 \%$ of the ionic budget, see Table 2) it will be neglected in the next equations. Samples showing ionic balance is a strong indication that all significant soluble species have been identified. From these samples we will try to determine in what compounds the ions were associated in the atmosphere. With

\begin{tabular}{|c|c|c|c|c|c|c|c|c|c|c|c|c|}
\hline $\begin{array}{c}\text { Location } \\
\text { (time period) }\end{array}$ & $\begin{array}{l}\text { Elevation } \\
\text { (A) }\end{array}$ & $\mathrm{Ne}^{*}$ & $\mathrm{NH}_{4}^{+}$ & $\mathrm{k}^{+}$ & $\mathrm{Ca}^{++}$ & $\mathrm{Mg}^{++}$ & $\mathrm{H}^{*}$ & $\mathrm{Cl}^{-}$ & $\mathrm{NO}_{3}^{-}$ & $\mathrm{SO}_{4}^{--}$ & $\Sigma$ & $x$ \\
\hline $\begin{array}{l}\text { Coastal areas } \\
\text { (recent years) }\end{array}$ & $0-850 \mathrm{~m}$ & $5.3 \pm 3.7$ & $0.2 \pm 0.0$ & $\begin{array}{c}0.1 \pm 0.1 \\
\text { (N) }\end{array}$ & $\begin{array}{l}0.2 \pm 0.2 \\
(\mathrm{~N})\end{array}$ & $\begin{array}{c}1.2 \pm 0.8 \\
(\mathrm{~N})\end{array}$ & $1.4 \pm 0.5$ & $\begin{array}{l}6.1 \pm 4.3 \\
(0.1 \pm 0.1)\end{array}$ & $0.4 \pm 0.2$ & $\begin{array}{l}1.4 \pm 0.5 \\
(0.8 \pm 0.4)\end{array}$ & $16.3 \pm 9.2$ & $1.8 \pm 0.0$ \\
\hline $\begin{array}{l}55 \\
(1959-1969)\end{array}$ & $\begin{array}{l}2025 \mathrm{at} \\
(7.0)\end{array}$ & $0.6 \pm 0.4$ & $0.2 \pm 0.1$ & $\stackrel{\mathbb{N}}{(\mathbb{N})}$ & (w) & $0.1 \pm 0.1$ & 1.3 & $0.7 \pm 0.4$ & $0.5 \pm 0.2$ & $\begin{array}{l}1.0 \pm 0.4 \\
(0.9 \pm 0.4)\end{array}$ & 4.4 & $2.0 \pm 0.3$ \\
\hline $\begin{array}{l}\text { D } 80 \\
(1959-1969)\end{array}$ & $\begin{array}{l}2524 \mathrm{~m} \\
(23.0)\end{array}$ & $0.5 \pm 0.3$ & $0.1 \pm 0.0$ & $\stackrel{N}{(N)}$ & $\stackrel{N}{(N)}$ & $0.1 \pm 0.1$ & $1.9 \pm 0.5$ & $\begin{array}{l}0.7 \pm 0.4 \\
0.2 \pm 0.2\end{array}$ & $0.9 \pm 0.2$ & $\begin{array}{l}0.8 \pm 0.3 \\
(0.7 \pm 0.3)\end{array}$ & $5.0 \pm 1.0$ & $2.9 \pm 1.0$ \\
\hline $\begin{array}{l}\text { Dome C } \\
(1959-1969)\end{array}$ & $\begin{array}{r}3240 \mathrm{~m} \\
(3.4)\end{array}$ & $1.0 \pm 0.3$ & $0.1 \pm 0.0$ & $0.1 \pm 0.0$ & $\stackrel{N}{(N)}$ & $\frac{0.2 \pm 0.1}{(N)}$ & $2.1 \pm 0.5$ & $\begin{array}{l}1,9 \pm 0.3 \\
(0.8 \pm 0.5)\end{array}$ & $0.2 \pm 0.0$ & $\begin{array}{l}1.6 \pm 0.4 \\
(1.3 \pm 0.4)\end{array}$ & $7.2 \pm 1.3$ & $3.9 \pm 2.9$ \\
\hline $\begin{array}{l}\text { Dowe C } \\
(1860-1880)\end{array}$ & $\begin{array}{r}3240 \mathrm{~m} \\
(3.4)\end{array}$ & $1.0 \pm 0.3$ & $0.1 \pm 0.1$ & $\begin{array}{l}\mathrm{N} \\
(\mathrm{N})\end{array}$ & $\stackrel{N}{(N)}$ & $\underset{(\mathrm{N})}{0.2 \pm 0.1}$ & $1.4 \pm 0.6$ & $\left\{\begin{array}{l}0.5 \pm 0.2 \\
(-0.6 \pm 0.3)\end{array}\right.$ & $0.3 \pm 0.1$ & $\begin{array}{l}1.7 \pm 0.5 \\
(1.6 \pm 0.5)\end{array}$ & $5.2 \pm 1.0$ & $0.9 \pm 0.2$ \\
\hline $\begin{array}{l}\text { South Pole } \\
(1959-1969)\end{array}$ & $\begin{array}{c}2850 \mathrm{~m} \\
(8.5)\end{array}$ & $0.6 \pm 0.3$ & $0.1 \pm 0.1$ & $\stackrel{N}{N}$ & $\stackrel{N}{N}$ & $\begin{array}{r}0.1 \pm 0.0 \\
(\mathrm{~N})\end{array}$ & $3.1 \pm 0.7$ & $\begin{array}{l}1.3 \pm 0.3 \\
(0.5 \pm 0.3)\end{array}$ & $1.5 \pm 0.2$ & $\begin{array}{l}1.2 \pm 0.4 \\
(1.0 \pm 0.4)\end{array}$ & $8.0 \pm 1.2$ & $2.9 \pm 0.6$ \\
\hline $\begin{array}{l}\text { Dome C } \\
(15,500-23,000 \\
\text { years B.P. })\end{array}$ & $\begin{array}{l}3240 \mathrm{~m} \\
(3.4)\end{array}$ & $3.8 \pm 0.8$ & $0.1 \pm 0.1$ & $\begin{array}{l}0.2 \pm 0.0 \\
(0.1 \pm 0.0)\end{array}$ & $\begin{array}{l}1.8 \pm 0.7 \\
1.7 \pm 0.7\end{array}$ & $\begin{array}{l}1.5 \pm 0.4 \\
(0.6 \pm 0.3)\end{array}$ & $1.9 \pm 0.4$ & $\begin{array}{l}4.6 \pm 1.0 \\
(0.2 \pm 0.6)\end{array}$ & $0.6 \pm 0.2$ & $\begin{array}{l}3.9 \pm 1.1 \\
(3.4 \pm 1.0)\end{array}$ & $18.3 \pm 4 . \mathrm{C}$ & $01.9 \pm 0.3$ \\
\hline
\end{tabular}
this aim, let us distinguish the snow corresponding at recent years from the ice deposited 18,000 years B.P.

Table 2 : Ionic distribution (in $\mu \mathrm{Eq} \cdot 1^{-1}$ ) and $\mathrm{C}-\mathrm{f} / \mathrm{Na}$ ratio ( $r$ ) at various locations ( $A$ is the accumulation rate in $\mathrm{g} \cdot \mathrm{cm}^{-2} \cdot \mathrm{yr}^{-1}$ ). Other numbers written in parentheses represent the non sea salt contribution of the ion. N notation is used when the concentration is lower than $0.1 \mathrm{\mu Eq}^{-1} 1^{-1}$. For these calculations, we have discarded from the 1959-1969 time period the years 1964 and 1965 which are perturbed by volcanic debris from Mt Agung (1963). 


\subsection{Recent years}

According to the terminology_used in_geochemistry, we have called excess $-x$, noted $\mathrm{X}^{*}$ (with $\mathrm{X}=\mathrm{K}^{+}, \mathrm{Ca}^{++}, \mathrm{Mg}^{++}, \mathrm{C1}^{-}$or $\mathrm{so}_{4}^{-}$) the non sea salt contribution of an ion $\mathrm{X}$. By subtracting the sea salt contribution from the equation (4) we obtain :

$\left[\mathrm{K}^{+}\right] *+\left[\mathrm{Ca}^{++}\right] *+\left[\mathrm{Mg}^{++}\right] *+\left[\mathrm{H}^{+}\right]=[\mathrm{Cl}] *+\left[\mathrm{NO}_{3}\right]+\left[\mathrm{SO}_{4}^{-}\right] *$

As previously discussed (Boutron (12), Legrand and Delmas (6), Legrand and De lmas (13)) oux present data (Table 2) confirm that in areas located below $2000 \mathrm{~m}$ elevation, Potassium, Calcium, Magnesium and Chloride are essentially derived from sea salt $\left(\left[\mathrm{K}^{+}\right] *=\left[\mathrm{Ca}^{++}\right] *=\left[\mathrm{Mg}{ }^{++}\right]^{*}=\left[\mathrm{Cl}^{-}\right] *=0\right)$. Thereby the equation (5) can be
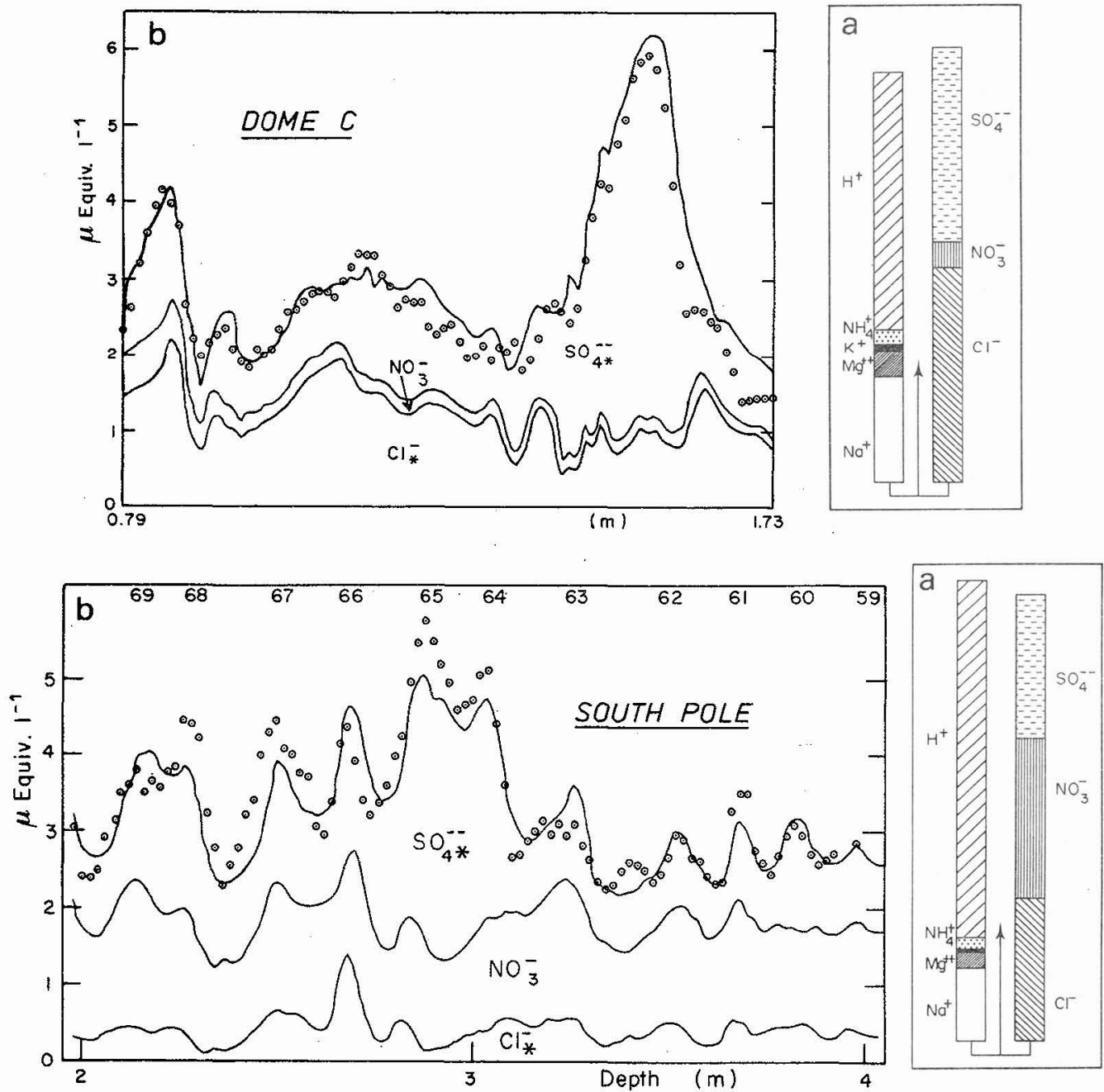

Figure 1: Comprehensive study of soluble ionic impurities in snow deposited at the South Pole (S.P.) and Dome C (D.C.) between 1959 and 1969. (a) mean ion balance - (b) acid reconstruction curve : the upper curve refers to the sum : $[\mathrm{Cl}]^{*}+\left[\mathrm{SO}_{4}\right]^{*}+\left[\mathrm{NO}_{3}\right]$, dots are measured acidity $[\mathrm{H}]$. 
reduced to :

$$
\left[\mathrm{H}^{+}\right]=\left[\mathrm{NO}_{3}\right]+\left[\mathrm{SO}_{4}^{--}\right] *
$$

Therefore in coastal areas, the soluble species essentially originate from sea salt and from two acids (nitric and sulfuric).

In other locations (D 80, South Pole and Dome C), we observe generally an excess of chloride ( $\mathrm{Cl} / \mathrm{Na}$ values in snow ( $\mathrm{r}$ ) being higher than the bulk sea water reference value 1.8 ) and the basic equation can be written :

$$
\left[\mathrm{H}^{+}\right]=\left[\mathrm{NO}_{3}\right]+\left[\mathrm{SO}_{4}^{--}\right] *+[\mathrm{Cl}] *
$$

This equation describes the acid components and demonstrates that snow from the central Antarctic plateau contains sea salt, $\mathrm{HCl}, \mathrm{HNO}_{3}$ and $\mathrm{H}_{2} \mathrm{SO}_{4}$. Figure 1 is an example of graphical checks of the equation (7) for Dome $\mathrm{c}$ and ${ }^{2}$ South Pole over the 1959-69 time period. But in other snow layers from central areas we observe negative values of the excess-chloride ( $r \leq 1.8$ ) (Table 2). As discussed in more detail elsewhere (Legrand and Delmas (13)), we have demonstrated that in this case, one fraction of the excess-sulfate corresponds to this chloride depletion and is in the form of $\mathrm{Na}_{2} \mathrm{SO}_{4}$. Therefore, in this particular case we have only two acids ( $\mathrm{HNO}_{3}$ and $\mathrm{H}_{2} \mathrm{SO}_{4}$ ) and a sulfate enriched sea salt.

\subsection{Aged ice (18.000 years B.P.)}

At Dome $\mathrm{C}$, significant excess of $\mathrm{Ca}^{++}, \mathrm{Mg}^{++}$and in a less degree $\mathrm{K}^{+}$is observed during the late glacial maximum (L.G.M.) while the $\mathrm{Cl} / \mathrm{Na}$ ratio remains very close to the 1.8 reference value (Table 2). In this case, equation (5) becomes:

$$
\left[\mathrm{H}^{+}\right]+\left[\mathrm{Ca}^{++}\right] *+\left[\mathrm{Mg}^{++}\right] *=\left[\mathrm{NO}_{3}\right]+\left[\mathrm{SO}_{4}^{-}\right] *
$$

Moreover, the good correlations observed between the calcium and magnesium excess and the aluminium content ( 0.93 and 0.80 , respectively, for 16 samples) suggest strongly that these excess values of alkaline soil have a terrestrial origin. Terrestrial dust contains usually significant amount of soluble species such as $\mathrm{CaSO}_{4}$ (Gypsum) and $\mathrm{CaCO}_{3}$ (Calcite). In these cases, due to the possible presence of $a^{4}$ basic compound $\left(\mathrm{CaCO}_{3}\right)$ in the ice, it is impossible to identify the chemical compounds only by examination of the ionic balance. Indeed, we cannot distinguish between the presence of a mixture "CaCO $3, \mathrm{H}_{2} \mathrm{SO}_{4}$ ", case $\mathrm{C}, \mathrm{Fig}$. 2) and the only $\mathrm{CaSO}_{4}$ (case $\mathrm{A}$ ) in the ice, because during the melting step $\mathrm{H}_{2} \mathrm{SO}_{4}$ and $\mathrm{CaCO}_{3}$ react
according to the reaction :

$$
\mathrm{CaCO}_{3}+\mathrm{H}_{2} \mathrm{SO}_{4} \longrightarrow\left(\mathrm{Ca}^{++}, \mathrm{SO}_{4}^{--}\right)+\mathrm{CO}_{2}^{+}+\mathrm{H}_{2} \mathrm{O}
$$

On one of these core sections we have performed $\mathrm{CO}_{2}$ measurements both by dry extraction method (14) (which measures the $\mathrm{CO}_{2}$ content ${ }^{2}$ of the bubbles) and by wet extraction (14) (which measures the total $\mathrm{Co}_{2}^{2}$ both from the bubbles and released from the lattice). No significant difference is observed, and we can discard the third assumption reported in Figure 2. This absence of natural carbonates and some other geochenical considerations (Legrand (8)) allow us to suggest that these alkaline soil-excesses are associated with both sulfate and nitrate (case B, Figure 2). These data demonstrate that the ice deposited in central Antarctica during the late glacial maximum contains sea salt, terrestrial salts (mainly Caso 4 and $\mathrm{MgSO}_{4}$ ) and two acids ( $\mathrm{HNO}_{3}$ and $\mathrm{H}_{2} \mathrm{SO}_{4}$ ).

\section{SPATIAL AND TEMPORAL VARIATIONS OF SNOW AND ICE CHEMISTRY}

As discussed above in detail, the bulk impurity composition of ice cores consists of microparticles (mainly aluminosilicates, insoluble in water), sea sa 1 t (mainly, $\mathrm{NaCl}$ with sometimes significant amounts of $\mathrm{Na}{ }_{4} \mathrm{SO}_{4}$ and some $\mathrm{SO}_{4}, \mathrm{Ca}^{++}, \mathrm{Mg}^{++}$and $\mathrm{K}^{+}$), terrestrial salts ( $\mathrm{CaSO}, \mathrm{MgSO}_{4}$ ) and acids ( $\mathrm{HNO}_{3}, \mathrm{H}_{2} \mathrm{SO}_{4}$ and sometimes $\mathrm{HCl}$ ). In
this section we examine the respective contribution of each fraction and its spatial and temporal variation. First, for each location we have evaluated the 

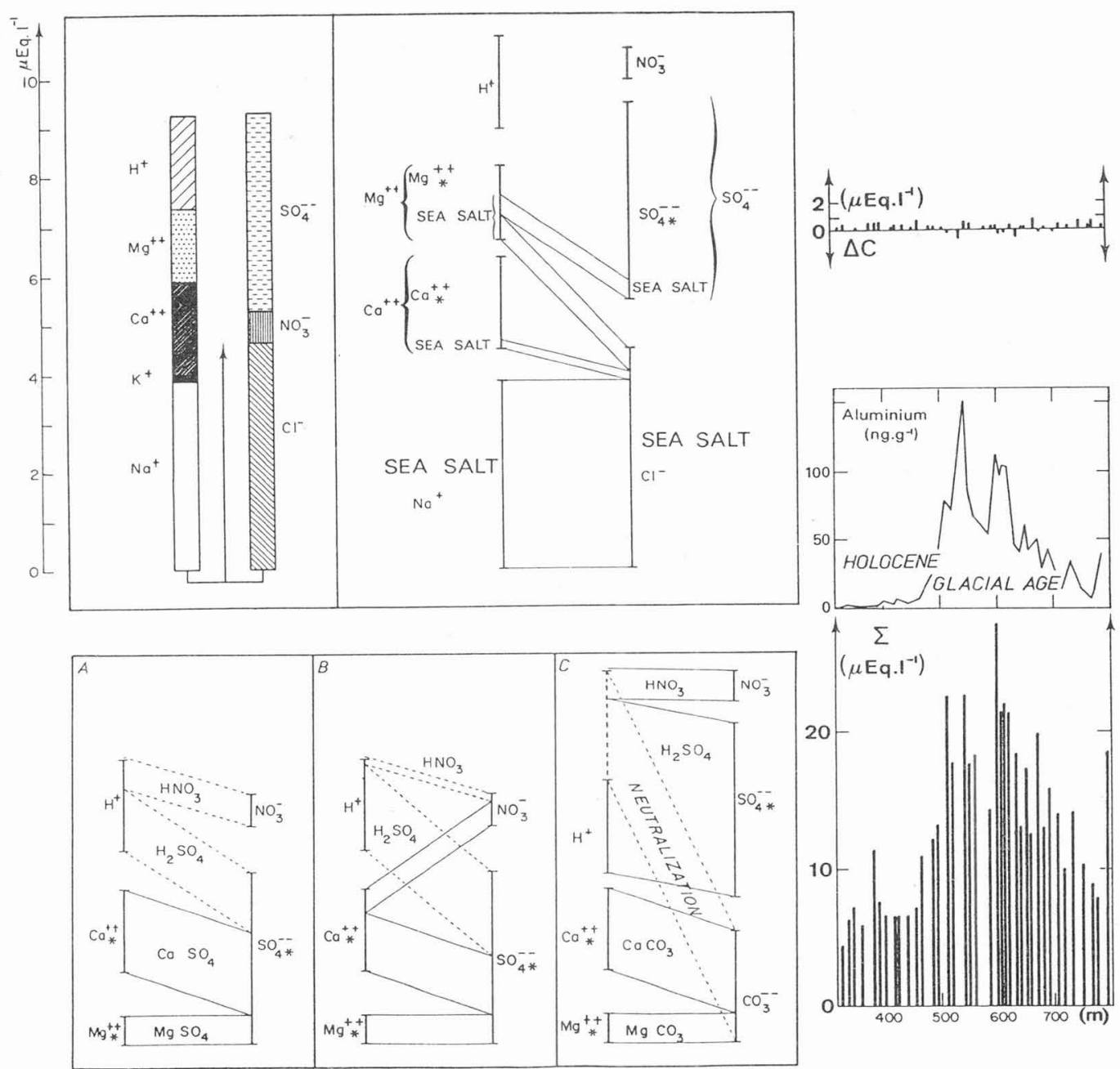

Figure 2 : On right side : variations of $\Delta \mathrm{C}, \Sigma$ (see text) and $A 1$ content during the period of the last climatic change (Holocene - L.G.M.) at Dome C. On the left hand side : mean ion balance in snow deposited during the L.G.M. and the three possible associations between $\mathrm{H}^{+}, \mathrm{Ca}^{++}{ }_{*}, \mathrm{NO}_{3}$ and $\mathrm{SO}_{4}{ }^{-*}$.

mass distribution of soluble and insoluble fractions. The insoluble mass is deduced from Aluminium content using the composition of mean crust as proposed by Taylor (10). Second, the contributions of sea salt, terrestrial salts and acids to the soluble part have been calculated in East Antarctica with our data (Table 2). In order to add to the picture, we have also used data obtained by Palais and Legrand ( 7$)$ at Byrd (1530 m elevation, in West Antarctica). 
During the Holocene stage, insoluble species represent only 5 to $10 \%$ of the total mass at each location (Table 3). In the same way, terrestrial salts do not contribute significantly to the soluble part. In typical coastal areas, sea salt is predominant ( $85 \%$ of the ionic budget) but this contribution decreases rapidly in more central areas. Indeed, above $2000 \mathrm{~m}$ elevation, the acid contribution becomes predominant (up to 70-80 \% of the ionic budget). The acid contribution remains stable in all locations, but due to a large scattering of $\mathrm{HCl}$ and $\mathrm{HNO}_{3}$ content, we can observe some important variations of their compositions (see Table 3). Finally we observe that the sea salt contribution is an efficient mean of distinguishing between East and West Antarctica, with $27 \%$ and $48 \%$ of the ionic budget, respectively. For Greenland ice cores (Holocene stage) the best available data are from Hammer et al. (15) who found a close balance between anions and cations at Dye 3. From these data we have calculated the ionic and mass distributions (Table 3). We can observe that the insoluble part is more important in Greenland than in Antarctica. Another important difference is the significant leve 1 of $\mathrm{NH}^{+}\left(0.3 \mathrm{\mu Eq} \cdot 1^{-1}\right)$ observed in Greenland ice cores. As suggested by Busenberg and Langway (16), we have assumed that this ion is present in the ice as $\left(\mathrm{NH}_{4}\right)_{2} \mathrm{SO}_{4}$. Because sources of $\mathrm{NH}_{3}$ are essentially located on continental areas, we have Identified the contribution of this compound as terrestrial salts in Table 3 . So higher contributions of insoluble species and $\left(\mathrm{NH}_{4}\right)_{2} \mathrm{SO}_{4}$ in Greenland are probably linked with a stronger continental influence 2 Greenland than in Antarctica.

During the late glacial maximum, insoluble species (as suggested by the Aluminium profile, see Figure 2) and in a less degree (see $\sum$ on Figure 2) soluble species show higher concentrations than during the Holocene stage. In this ice, insoluble species become predominant, representing a good half of the total mass. In the same way, terrestrial salt contents which are insignificant during the Holocene stage represent here $25 \%$ of the ionic budget. The sea salt contribution is doubled ( $50 \%$ of the ionic budget) while the acid contribution is reduced to $20 \%$. Until now, no comprehensive study of the ice stage has been performed in Greenland, but several studies have pointed to a strong contribution of alkaline, Ca-rich, dust. It is also important to notice that in this ice the acid contribution is reduced to zero, as suggested by the extremely low currents observed by Hammer (17) and Hammer et al. (15) from solid conductivity measurements

\begin{tabular}{|c|c|c|c|c|c|c|}
\hline Location (time period) & $\begin{array}{l}\text { Soluble } \\
\text { sea salt }\end{array}$ & $\begin{array}{l}\text { species } \\
\mathrm{HC} 1\end{array}$ & $\begin{array}{l}\text { (\% of the } \\
\mathrm{HNO}_{3}\end{array}$ & $\begin{array}{l}\text { ionic b } \\
\mathrm{H}_{2} \mathrm{SO}_{4}\end{array}$ & $\begin{array}{l}\text { budget) } \\
\text { terrestrial }\end{array}$ & $\begin{array}{l}\text { Distribution (7 in mass } \\
\text { of insoluble species) }\end{array}$ \\
\hline Cosatal areas (recent years) & 85 & N & 5 & 10 & $\mathbf{N}$ & 27 \\
\hline D $55(1959-1969)$ & 34 & $\mathbf{N}$ & 23 & 41 & N & 97 \\
\hline (D $80(1959-1969)$ & 24 & 7 & 36 & 28 & $\mathrm{~N}$ & $8 q$ \\
\hline South Pole (1959-1969) & 21 & 13 & 38 & 25 & $\mathrm{~N}$ & $7 \%$ \\
\hline Dome C (1959-1969) & 36 & 22 & 6 & 36 & $\mathrm{~N}$ & 67 \\
\hline Byxd (Holocene) & 48 & $\mathrm{~N}$ & 23 & 25 & $\mathrm{~N}$ & $10 ?$ \\
\hline Done C (glacial age $)$ & 54 & $\mathrm{~N}$ & 2 & 16 & 26 & $62 ?$ \\
\hline $\begin{array}{l}\text { Dye } 3 \text { (Holocene) } \\
\text { Greenland }\end{array}$ & 25 & $N$ & 50 & 7.5 & $15 *$ & $30 Z$ \\
\hline
\end{tabular}

Table 3 : Ionic distribution of soluble species and distribution in mass of insoluble species. The value noted by $(*)$ corresponds to the contribution of $\left(\mathrm{NH}_{4}\right) \mathrm{SO}_{4}$ (see text). For the 1959-1969 time period we have calculated the nass of insoluble species by using data from Boutron (21). N notation is used when the fraction is lower than $1 \%$. 
It is useful to keep in mind that chemical compositions reported in Tables 2 and 3 can be strongly modified during high volcanic activity periods. After an eruption of global significance, it is generally observed an increase in the $\mathrm{H}_{2} \mathrm{SO}_{4}$ content of ice both in Greenland and Antarctica (see, as an example, the perturbation occurring after the Agung $\left(8^{\circ} \mathrm{S}\right)$ eruption in Figure 1$)$. Moreover, local eruptions can disturb the $\mathrm{HCl}$ and $\mathrm{HF}$ contribution of the ice. This is particularly true for Greenland (Hammer (17)) which is surrounded by important volcanic centres (Alaska, Kamtchatka and Iceland).

\section{INCORPORATION OF IMPURITIES IN THE ICE}

In preceding sections we have identified major chemical compounds present in the ice.But it is also useful to have an idea of the localization of these impurities in the lattice. It is generally proposed, but no proved, that impurities are located at grain boundaries. Indeed, due to the recrystallization processes in the ice sheet, impurities should be located on the outside of the grain. However, this phenomena could be very different depending on the composition of compounds and also on the inclusion mechanism in the snow flakes.

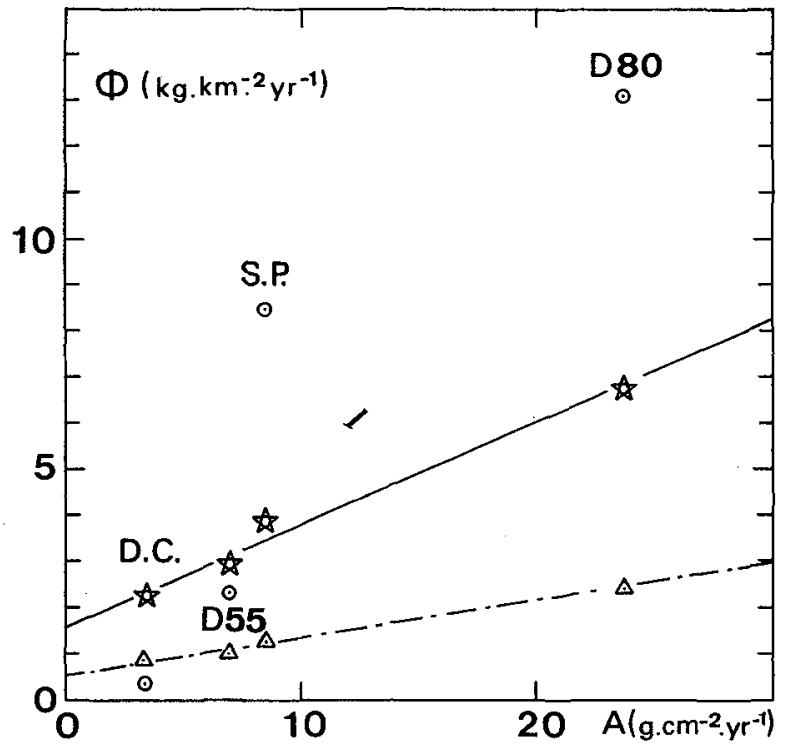

Figure 3 : Circles: mean deposition fluxes of $\mathrm{NO}_{3}^{-}(\Phi)$ at Dome C $\left(D^{3} \mathrm{C}.\right), \mathrm{D} 55, \mathrm{D} 80$ and South Pole (S.P.) as a function of the snow accumulation rate (A) between 1959 and 1969. Solid line refers to the mean deposition of $\mathrm{H}_{2} \mathrm{SO}_{4}$ obtained from the same samples (stars), broken line refers to the mean deposition of sea salt (triangles).

Table 2 shows that sea salt and $\mathrm{H}_{2} \mathrm{SO}_{4}$ concentrations decrease with increasing accumulation rate. But this dilution effect is not evident for nitrate. In order to evaluate the dry and wet deposition of impurities we have plotted the deposition fluxes $(\phi)$ as a function of snow accumulation rates (A) for $\mathrm{Na}^{+}$ (indicator of sea salt) sulfate-excess $\left(\mathrm{H}_{2} \mathrm{SO}_{4}\right.$ ) and $\mathrm{NO}_{3}^{-}\left(\mathrm{HNO}_{3}\right)$ (Figure 3 ). We have discarded $\left(\mathrm{Cl}^{-}\right) *$ because HCI is not present at all locations. These calculations were performed on snow layers deposited during the same period (1959-1969) at four Antarctic locations (D 55, D 80, Dome C and South Pole). The diagram indicates that there is a clear relationship between $\phi$ and $A$ for sea salt and $\mathrm{H}_{2} \mathrm{SO}_{4}$. Flux values extrapolated to accumulation rates maller than $3.4 \mathrm{~g} \cdot \mathrm{cm}^{-2} \cdot \mathrm{yr}^{-1} \mathrm{give}^{2}$ a Y-intercept of 0.5 and $1.6 \mathrm{~kg} \cdot \mathrm{km}^{-2} \cdot \mathrm{yr}^{-1}$ for sea salt and $\mathrm{H}_{2} \mathrm{so}_{4}$ respectively. Because we don't know the relationship between $\Phi$ and $A$ at very $10^{4}$ accumulation rates, the assumption that the Y-intercept represents the dry flux is strongly debatable. However at Dome $\mathrm{C}$ a maximum of $60 \%$ of sea salt and $70 \%$ of $\mathrm{H}_{2} \mathrm{SO}_{4}$ can be deposited directly on the snow surface.

For nitrate fluxes a large scattering can be observed (Figure 3), which may be due to the uneven atmospheric concentrations of this compound (Legrand and Delmas 
(18)). However, as shown in Figure 3, the rather low values of the Y-intercept suggests low dry deposition of this compound. Assuming that this low value is real, $\mathrm{HNO}_{3}$ is essentially trapped in snow flakes. Therefore the incorporation of HNO and $\mathrm{H}_{2} \mathrm{SO}_{4}$ seem to be different. This difference could be explained by the physical form which is very different for these two compounds in the Antarctic atmosphere. Indeed $\mathrm{H}_{2} \mathrm{SO}_{4}$ is present as small droplets of hydrated sulfuric acid (Shaw (19)) fixed on large solid particles (seasalt or terrestrial dust (Kumai (20)). In contrast, HNO which is not observed on aerosols in the Antarctic atmosphere, is probably present in gaseous phase (as also suggested by thermodynamic arguments). Moreover $\mathrm{HNO}_{3}$ is extremely soluble in water. These arguments could explain the relatively high fraction of wet deposition. Further experiments in the atmosphere and on fresh snow flakes are needed to understand the incorporation of nitric acid in snow.

\section{CONCLUSION}

In this study we have investigated the soluble part of impurities present in Antarctic snow and ice. The very close balance between cations $\left(\mathrm{Na}^{+}, \mathrm{NH}_{4}^{+}, \mathrm{K}^{+}, \mathrm{Ca}^{++}\right.$ $\left.\mathrm{Mg}^{++}, \mathrm{H}^{+}\right)$and anions $\left(\mathrm{Cl}^{-}, \mathrm{NO}_{3}, \mathrm{SO}_{4}^{-}\right.$) generally observed suggests that we have studied all ions present in Antarctic precipitation. The presence of sea salt, three mineral acids ( $\mathrm{HNO}_{3}, \mathrm{H}_{2} \mathrm{SO}_{4}$ and $\mathrm{HCl}$ ) and sometimes terrestrial salts is demonstrated. The relative contribution of each chemical compound is variable, depending on the location and the considered time period, but the important role of acids in snow deposited in the central plateau during recent years is clearly demonstrated. The incorporation of these impurities in snow is still not well understood and is probably very different depending on their physical state in the atmosphere (aerosol or gas).

\section{ACKNOWLEDGEMENTS}

The Centre National de la Recherche Scientifique and the Ministere de 1 'Environnement funded this study. Fieldwork was supported by TAAF and NSF (Division of Polar Programs).

\section{REFERENCES}

(1) Petit J.R., Ezat U., Barkov N.I. and Petrov V.N., Scanning electron microscopy, 4 (1983) $1627-1633$.

(2) Cragin J.M.- Herron M.M., Langway C.C. and Klouda G., "Polar Oceans", Ed. D. Dunbar (1977) $617-631$.

(3) Petit J.R., Briat M. and Royer A., Nature, 293 (1981) 391-394.

(4) De Angelis M., Legrand M., Petit J.R., Barkov N.I. Korotkevich Y.S. and Kot lyakov V.M., J. Atmos. Chem., I (1984) $215-239$.

(5) Legrand $M$. and Delmas R.J., Atmos- Environ.,18 (1984) 1867-1874.

(6) Legrand M. and Delmas R.J., Ann Is Glaciol., 7 (1985) $20-25$.

(7) Palais J. and Legrand M., J. Geophys. Res., 90 (1985) $1143-1154$.

(8) Legrand $M .$, These d'Etat, Publication $\mathrm{N}^{\circ} 478$ du Laboratoire de Glaciologie de Grenoble , 439 p. (1986).

(9) Legrand M., De Angelis M. and Delmas R.J., Anal. Chim. Acta, 156 181-192.

(10) Taylor S.R., Geochim. Cosmochim. Acta, 28 (1964) 1273.

(11) Legrand M., Aristarain A.J. and Delmas R.J., Anal. Chem., 54 (1982) $1336-39$.

(12) Boutron C., Atmos. Environ., 13 (1979) $919-924$.

(13) Legrand M. and Delmas R.J., submitted to J. Geophys. Res.

(14) Delmas R.J., Ascencio J.M. and Legrand M., Nature, 284 (1980) $155-157$.

(15) Hammer C.H., Clausen H.B., Dansgaard W., Neftel A., Kristinsdottir P. and Johnston E., The Greenland Ice Sheet: Program, Am. Geophys. Union, Geophys. Monogr. (1985) $90-94$.

(16) Busenberg E. and Langway C.C. Jr, J. Geophys. Res, , 84 (1979) $1705-09$.

(17) Hammer C.U., J. of Glaciol., 25 (1980) $359-372$.

(18) Legrand $M$. and Delmas R.J., Tellus $(1986)$, in press.

(19) Shaw G.E., Atmos. Environ. 17 (1983) 329.339.

(20) Kumai M., J. Atmos. Sci., 33 (1976) $883-841$.

(21) Boutron C., These d'Etat, Fublication $N^{*} 238$ du Laboratoire de Glaciologie de Grenoble, 283 p. (1978). 